\title{
CARDIAC EFFECTS OF SUCCINYLDICHOLINE AND SUCCINYLMONOCHOLINE
}

\author{
Akito Ohmura, K.C. Wong, and Lynn Shaw
}

ALTHOUGH THE NEUROMUSCULAR BLOCKING EFFECT of succinylcholine is reasonably understood, its cardiac effects are varied and still require clarification. Clinically, hypertension and hypotension, bradycardia and tachycardia as well as dysrhythmia are not infrequently seen during continuous infusion or during repeated intravenous injection of succinylcholine. ${ }^{1-4}$

Succinyldicholine and its first step hydrolyzed product succinylmonocholine are structurally similar to acetylcholine.<smiles>CC#[N+]CCOC(C)=O</smiles>

ACETYLCHOLINE<smiles>C[N+](C)=CC[N+](C)=CCCOC(=O)CCC(=O)OC(C)(Cl)Cl</smiles>

\section{SUCCINYLDICHOLINE}<smiles></smiles>

SUCCINYLMONOCHOLINE

Several mechanisms of action have been postulated for the cardiac effects of succinyldicholine. These are:

1. Direct action on atrial muscarinic receptors and possibly multiple muscarinic and nicotinic receptors in the ventricle..$^{5,6}$

2. Stimulation of postganglionic parasympathetic fibres to autonomic effector cells. ${ }^{7}$

3. Stimulation of preganglionic autonomic fibres to sympathetic and parasympathetic ganglion cells and to the adrenal medulla. ${ }^{7}$

4. Stimulation of vagal centres or through sensory receptors of carotid or aortic body and carotid sinus. ${ }^{8,9}$

Akito Ohmura, M.D., Anaesthesia Research Fellow; K.C. Wong, M.D., Ph.D., Associate Professor of Anaesthesiology \& Pharmacology; Lynn Shaw, B.S., Research Specialist, Departments of Anesthesiology \& Pharmacology, University of Utah College of Medicine, Salt Lake City, Utah, 84132 .

This data was presented at the American Society of Anesthesiologist Meeting, October 1975, Chicago. This study is supported in part from a grant funded by the Utah Heart Association. 
The present study evaluates the possible role of succinylmonocholine in the production of some of these cardiac effects. The rabbit was chosen as the experimental animal because it has a low level of plasma cholinesterase ${ }_{1}^{10}$ thus allowing greater ease of interpretation of in vivo responses to repeated injections of succinylcholine and comparative studies could be done in isolated rabbit hearts where extra-cardiac effects were eliminated.

\section{Methods}

\section{In Vitro Study}

Isolated hearts of albino rabbits were perfused through the aorta in a modified Langendorf preparation as previously described. ${ }^{11} \mathrm{~A}$ constant column of perfusate of $50 \mathrm{~cm} \mathrm{H} \mathrm{H}_{2} \mathrm{O}$ over the aortic valve was maintained with the use of a run-off arm. The perfusate was Chenoweth solution, containing $\mathrm{NaCl} 119.8 \mathrm{mM}, \mathrm{KCl} 5.63 \mathrm{mM}$, $\mathrm{CaCl}_{2} 2.16 \mathrm{mM}, \mathrm{MgCl}_{2} 2.10 \mathrm{mM}$, dextrose $10 \mathrm{mM}$ and $\mathrm{NaHCO}_{3} 25.0 \mathrm{mM}$ at $\mathrm{pH} 7.4$. This was gassed with 95 per cent $\mathrm{O}_{2}$ and 5 per cent $\mathrm{CO}_{2}$ at constant temperature $37^{\circ} \mathrm{C}$ regulated with a Lauda Thermo-regulator. Left ventricular pressure (LVP) and $\mathrm{LV} \mathrm{dp} / \mathrm{dt}$ were recorded from a 14 gauge needle inserted through the left ventricular muscle, with the needle attached to a high frequency Microdot pressure transducer. The cardiac electrogram was monitored with platinum electrodes in the right atrial appendage and the left ventricular wall one centimetre from the apex.

When the preparation was stabilized it was perfused for 15 minutes with a freshly prepared drug solution, during which time observations were made. After perfusion with one solution, the heart was perfused for 15 minutes with control solution before changing to the next drug solution. The perfusate was not recirculated. Twenty-six hearts were perfused in four groups.

Group 1 (7) were perfused with 20,50 , and $100 \mathrm{mg} / \mathrm{l}$ succinyldicholine solution; Group 2 (7) were perfused with 20,50 and $100 \mathrm{mg} / \mathrm{l}$ succinyl monocholine solution;

Group 3 (7) were perfused with mixed solutions of succinyl dicholine and succinyl monocholine equivalent to above concentration;

Group 4 (5) were pretreated with intraperitoneal reserpine $5 \mathrm{mg} / \mathrm{kg} 24$ hours before the isolation of the hearts and perfused with succinyldicholine and/or succinylmonocholine.

\section{In Vivo Study}

Seven untreated rabbits and five rabbits pretreated with reserpine were anaesthetized with intravenous alpha-chloralose $(150 \mathrm{mg} / \mathrm{kg}$ ) and ventilated through a tracheostomy with 100 per cent $\mathrm{O}_{2}$ maintaining slightly hypocapnic arterial blood gas tensions. A cannula was introduced through the carotid artery into the left ventricle for blood sampling and pressure monitoring. Left ventricular pressure, LV dp/dt and ECG were continuously monitored with frequent checking of arterial blood gas and plasma $\mathrm{Na}$ and $\mathrm{K}$.

When these parameters became stable, repeated intravenous injections of succinyldicholine and succinyl monocholine were done through an external jugular vein. 


\section{RESULTS}

In vitro data are summarized in Table I.

1. Perfusion with succinyldicholine $(20,50$, and $100 \mathrm{mg} / \mathrm{l})$ produced more than 10 per cent to 15 per cent decrease in heart rate, left ventricular pressure and $\mathrm{dp} / \mathrm{dt}$ in five of seven preparations, without cardiac dysrhythmia.

2. Succinyl monocholine decreased the same parameters in four of seven preparations. However, there was a transient increase in LVP and LV dp/dt.

3 . The mixture of succinyl dicholine $(10-25-50 \mathrm{mg} / 1)$ and succinyl monocholine produced positive and negative chronotropic as well as inotropic responses with a significant number of ventricular extrasystoles in three of seven preparations.

4. Intraperitoneal pretreatment of rabbits with reserpine $(5 \mathrm{mg} / \mathrm{kg}) 24$ hours before study produced an increased number of spontaneous nodal beats and ventricular extrasystoles in the isolated hearts. These dysrhythmias were further potentiated by succinyldicholine and succinylmonocholine, which produced negative intropic and chronotropic responses.

5. Single bolus injections of succinyldicholine or succinylmonocholine $2 \mathrm{mg}$ or 4 $\mathrm{mg}$ through the side arm, close to the perfused heart, produced a diphasic response with initial increase of LVP and LV dp/dt and subsequent decrease of the same parameters plus bradycardia.

6. Atropine sulphate (1-2 mg) abolished the negative chronotropic responses described, but not the cardiac dysrhythmias.

In vivo data are summarized in Table II.

1. Repeated intravenous injections of succinyldicholine (1-2 $\mathrm{mg} / \mathrm{kg}$ ) at fiveminute intervals produced bradycardiac within five seconds followed by 10 per cent to 20 per cent increase in LVP and $L V \mathrm{dp} / \mathrm{dt}$ in all seven rabbits.

2. Repeated intravenous injection of succinylmonocholine ( $1-2 \mathrm{mg} / \mathrm{kg}$ ) produced the same but less profound results as succinyldicholine in six of seven rabbits.

3. When succinyldicholine $(0.5 \mathrm{mg}-2 \mathrm{mg} / \mathrm{kg})$ and succinylmonocholine $(0.5-2$ $\mathrm{mg} / \mathrm{kg}$ ) were injected together, there was marked increase in nodal and ventricular ectopic beats as well as positive inotropic responses in all seven rabbits. The latency time to onset of dysrhythmias was 30 seconds to one minute. Plasma potassium and sodium were within normal limits during these dysrhythmic episodes.

4. Atropine sulphate $(0.5 \mathrm{mg} / \mathrm{kg})$ intravenously abolished the bradycardia effect of succinyldicholine and succinylmonocholine and reduced, but did not abolish the dysrhythmic beats.

The following three groups in Table II consist of the reserpinized animals, animals with cord trans-sections at the level of the foramen magnum and animals with cord trans-section titrated with intravenous trimethaphan to obtain a steady state of LV dp/dt 80 per cent of control. In all three groups there was a transient immediate bradycardia, but without any effect on LVP or LV dp/dt. Animals with trans-section of the cord responded with transient cardiac dysrhythmias following injections of a mixture of succinyldicholine and succinylmonocholine, but these ceased spontaneously in less than two minutes. 


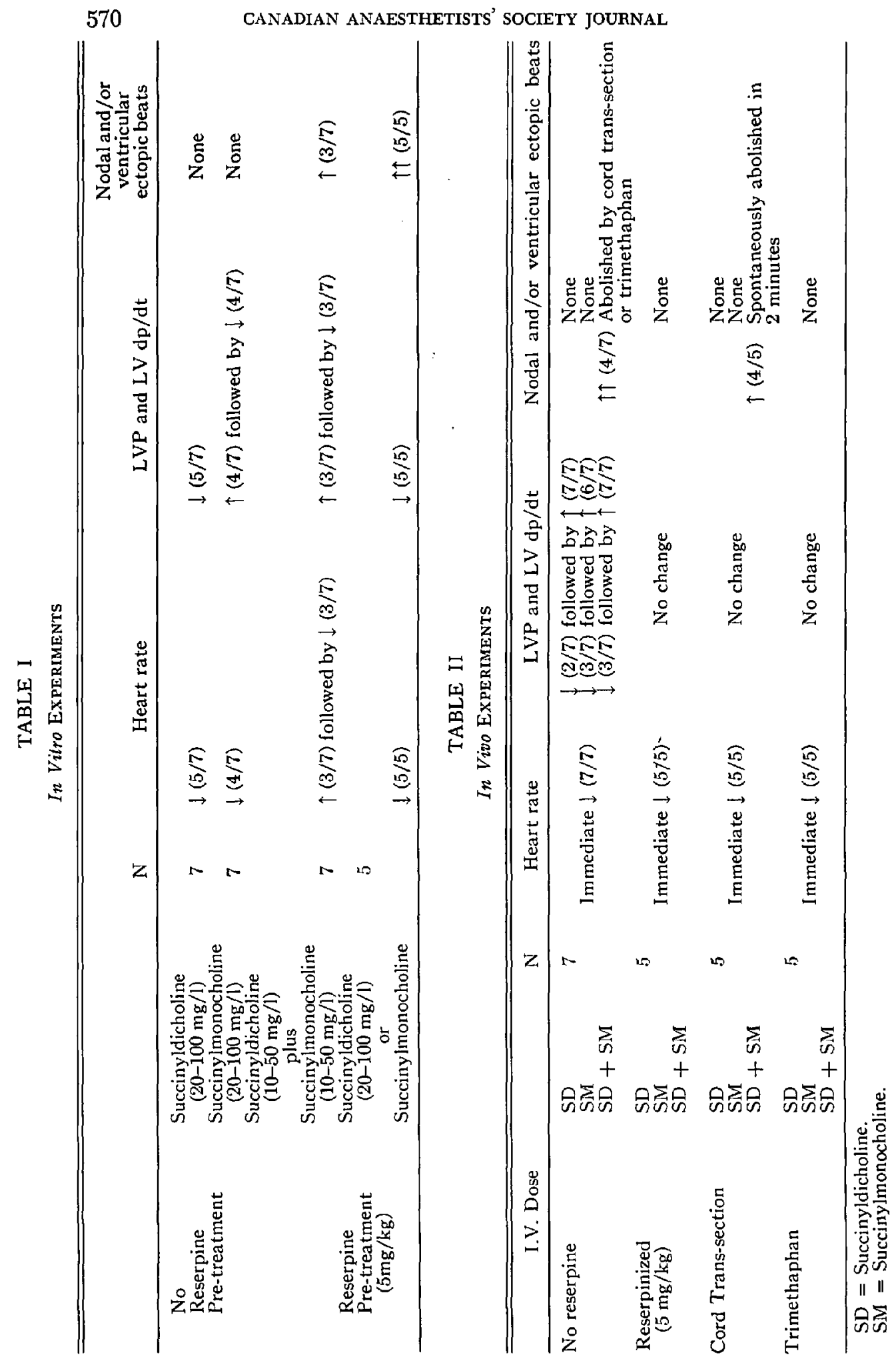




\section{Discussion}

Acetylcholine has been known to have a diphasic effect on the isolated papillary muscle of the rabbit in a dose related manner. Low doses produced negative chronotropic or inotropic effects, while large doses produced positive chronotropic and inotropic responses. The negative responses were abolished by atropine and nondepolarizing muscle relaxants. Goat ${ }^{12}$ found that succinylcholine also has a diphasic action on the isolated rabbit heart. These results suggest two possible types of receptors, muscarinic and nicotinic, in the heart.

In our in vitro study, perfusion with succinylmonocholine produced a diphasic response, an initial increase in LVP and $\mathrm{dp} / \mathrm{dt}$ being followed by a negative inotropic response. Positive response occurred in 1 to 5 minutes and the negative response followed in 5 to 12 minutes. Succinyldicholine produced only a negative chronotropic and inotropic response. Single bolus injection of succinyldicholine or succinylmonocholine (2-4 mg) through a side arm, close to the perfused hearts, produced immediate positive inotropic response followed by negative chronotropic and inotropic response. These negative cardiac responses were abolished by atropine.

These responses support the hypothesis that muscarinic and nicotinic receptors exist in the heart. Succinyldicholine may have a more potent direct muscarinic effect on the mycardium than succinylmonocholine.

The observation that a greater number of dysrhythmias occurred in reserpinized hearts in vitro and that these dysrhythmias were further potentiated by succinyldicholine and succinylmonocholine is not easy to interpret. The data suggest that the combination of the two drugs was more arrhythmogenic on the isolated heart. The arrhythmogenic effect was potentiated by a reduction in catecholamine stores in the heart. This dysrhythmia may possibly be mediated through type II receptors described by Buccino and Sonnenblick.5 They observed in the isolated cat papillary muscle preparation that denervation and reserpine did not abolish the positive inotropic response to acetylcholine and nicotine. They postulated the existence of type II receptors in the ventricular muscle which, unlike classical nicotinic receptors, do not require norepinephrine to exert the positive inotropic effect of acetylcholine.

In several of the untreated animals in vivo succinyldicholine and/or succinylmonocholine produced a negative inotropic response which was abolished by atropine. There was a sustained positive inotropic response in almost all animals which lasted more than one minute. These diphasic responses were abolished by trimethaphan, cord trans-section and reserpine, suggesting a centrally mediated as well as a peripheral effect. This could be a direct action on the vagal centre in the medulla or an indirect action of sensory receptors such as chemoreceptors or baroreceptors mediated through reflexes. Acetylcholine can increase frequency of impulses from the carotid sinus or carotid body. 8,9

The arhythmogenic effect of a mixture of succinyldicholine and succinylmonocholine was significant in vitro as well as in vivo. The latency time of onset of dysrhythmias in vivo was about 30 seconds to one minute. This was abolished by cord trans-section and trimethaphan, suggesting possible contribution from reflex mechanisms. Dysrhythmia was also produced when succinyldicholine was injected 
one minute after intravenous succinylmonocholine. When succinylcholine was given at intervals greater than 5 minutes following succinylmonocholine there was no dysrythmia produced, suggesting that some critical balance of the drugs is required in vivo to produce dysrhythmias. In one patient anaesthetized with cyclopropane, succinylmonocholine $40 \mathrm{mg}$ intravenously produced no change in heart rate or arterial pressure. ${ }^{4}$ Succinyldicholine $40 \mathrm{mg}$ intravenously 1 13. minutes following succinylmonocholine produced increased heart rate and arterial pressure. Subsequent injection of succinyldicholine produced bradycardia, but no obvious effect was observed with succinylmonocholine. ${ }^{4}$

In summary succinylmonocholine and succinyldicholine administered separately or together, produced bradycardia in experiments in vivo as well as in vitro. The combination of the two drugs has a direct arhythmogenic effect as well as an indirect reflexly mediated cardiac effect. Acetylcholine has potent muscarinic and nicotrinic effects. Because of structural similarities between acetylcholine, succinyldicholine, and succinylmonocholine, they could disturb the balance between the sympathetic and the parasympathetic systems. If muscarinic activity predominates, the sino-auricular node would be suppressed as the principal pacemaker. Since ventricular muscle is devoid of cholinergic fibers, simultaneous nicotinic stimulation could enhance other potential pacemakers of the heart, creating extrasystoles and cardiac dysrhythmias.

Since hydrolysis of succinyldicholine is a first-order reaction in plasma, the larger the dose given, the more succinylmonocholine will be produced in the blood. ${ }^{13}$ There may be a critical balance of the two drugs which could produce serious dysrhythmia especially in patients whose autonomic balance is already disturbed such as elderly patients, infants, digitalized patients, and patients in shock.

In our study, succinylmonocholine but not succinyldicholine produced positive inotropic and chronotropic responses in the isolated heart, but there was no evidence that succinylmonocholine itself produces more serious bradycardia, dysrhythmia or hypotension than succinyldicholine in vivo.

\section{SUMMARY}

The present study evaluated possible contribution of succinylmonocholine in producing serious cardiovascular effects with or without succinyldicholine, using albino rabbits as the experimental animal. Forty-eight experiments were performed, 22 in vivo and 26 in vitro (Langendort heart).

Succinyldicholine and succinylmonocholine administered separately or together, produced an immediate bradycardia in vivo as well as in vitro. The combination of these drugs had a direct arhythmogenic effect as well as an indirect reflex mediated cardiac effect. When succinyldicholine was given within five minutes following a dose of succinylmonocholine there was significant nodal and ventricular ectopic beats, but no bradycardia. Dysrhythmias in in vivo hearts were abolished by cord trans-section, trimethaphan and reserpine pretreatment. There was no evidence in vivo that succinylmonocholine produced more serious bradycardia, dysrhythmias or hypotension than succinyldicholine. 


\section{RÉsuMÉ}

Nous avons étudié les effets cardiovasculaires de la succinylmonocholine employée isolément ou en association à la succinyldicholine, ceci chez le lapin albinos.

En tout 48 expériences ont été faites, soit 24 in vivo et 24 in vitro (cceur de Langendort).

In vivo et in vitro, la succinyldicholine et la succinylmonocholine utilisées séparément ou en association produisaient une bradycardie immédiate. L'association des deux agents, en plus des effets indirects réflexes, était suivie fréquemment d'extrasystoles. Une injection de succinyldicholine donnée en dedans de cinq minutes après une dose de succinylmonocholine était fréquemment suivie d'extrasystoles ventriculaires ou de rythme jonctionnel mais ne produisait pas de bradycardie.

L'on pouvait abolir les troubles du rythme in vivo, soit par une section médullaire, soit par l'administration préalable de trimethapan ou de réserpine. In vivo, la succinyldicholine ne semblait pas produire plus de troubles du rythme, d'hypotension ou de bradycardie que le succinylmonocholine.

\section{ACKNOWLEDGMENTS}

The authors gratefully acknowledge Dr. Arthur P. Phillips, Burroughs Wellcome and Company, for supplying the succinylmonocholine and Mrs. Lu Ann Conley for her manuscript work.

\section{REFERENCES}

1. Galindo, A.H. \& Davis, J.B. Succinylcholine and cardiac excitability. Anesthesiology 23: 32 ( 1962 ).

2. Williams, C.H. \& Deutsch, S. Effects of intravenously administered succinylcholine on cardiac rate, rhythm and arterial blood pressure in anesthetized man. Anesthesiology 22: 947 (1961).

3. Purpura, D.P. \& Grundfest, H. Blockade of cardiac synapses by succinylcholine. Science 124: 319 (1956).

4. Williams, C.H., Deutsch, S., Linde, H.W., Bullough, J.W., \& Dripps, R.D. Effects of intravenously administered succinyldicholine on cardiac rate, rhythm and arterial blood pressure in anesthetized man. Anesthesiology 22: 947 (1961).

5. Buccino, R.A. \& Sonnenblick, E.H. Direct positive inotropic effect of acetylcholine on myocardium. Circulation Research 19: 1097 (1966).

6. DEMPSEY, P.J. \& COOPER, T. Ventricular cholinergic receptor systems; interaction with adrenergic system. J. Pharmacol. Exp. Ther, 167: 282 (1969).

7. Goodman, L.S. \& Grllman, F. The phamacological basis of Therapeutics. Edition 5 , Macmillan Pub. Co., Inc. (1975) Chap. 23: Parasympathomimetic agent, p. 467.

8. Dramond, J. Observation of the excitation by acetylcholine and by pressure of sensory receptors in the cats carotid sinus. J. Physiol. (London) 130: 513 (1955).

9. KonNER, P.I. Integrative neural cardiovascular control. Physiol. Review 51: 312 (1971).

10. Ecobichon, D.J. \& Comeau, A.M. Pseudocholinesterases of mammalian plasma; physiochemical properties and organophosphate inhibition in eleven species. Toxicol. Apl. Pharmacol. 24: 92 (1973).

11. Sullivan, D.L. \& WonG, K.C. The effects of morphine on the isolated heart during normothermia and hypothermia. Anesthesiology $38: 550$ (1973).

12. Goar, V.A. The effect of succinylcholine on the isolated mammalian heart. Proc. Roy. Soc. Med. 65: 149 (1972)

13. Ecer, II, E.I. The uptake and distribution of anesthetics. The Williams and Wilkins Co. Baltimore, Maryland (1974) Chap. 19: Muscle relaxant uptake and elimination, p. 314. 